OPEN ACCESS

Edited by:

Daniel John Blackwood, National University of

Singapore, Singapore

Reviewed by:

Santiago Fajardo,

Centro Nacional De Investigaciones Metalurgicas (CENIM), Spain

Faysal Eliyan,

University of British Columbia, Canada

*Correspondence: Yunhua Huang huangyh@mater.ustb.edu.cn

Lin Lu

Iu_lin@mater.ustb.edu.cn

Specialty section:

This article was submitted to Environmental Materials,

a section of the journa

Frontiers in Materials

Received: 02 August 2019 Accepted: 04 November 2019 Published: 21 November 2019

Citation:

Liu Y, Zhao Q, Zhao J, Huang Y, Cheng $X$ and Lu L (2019) Effect of Pre-passivation on the Corrosion Behavior of PH13-8Mo Stainless Steel in Industrial-Marine Atmospheric Environment. Front. Mater. 6:296 doi: 10.3389/fmats.2019.00296

\section{Effect of Pre-passivation on the Corrosion Behavior of PH13-8Mo Stainless Steel in Industrial-Marine Atmospheric Environment}

\author{
Yanning Liu ${ }^{1}$, Qiyue Zhao ${ }^{1}$, Jinbin Zhao ${ }^{2}$, Yunhua Huang ${ }^{1 *}$, Xuequn Cheng ${ }^{1}$ and Lin Lu ${ }^{1 *}$ \\ ${ }^{1}$ Corrosion and Protection Center, University of Science and Technology Beijing, Beijing, China, ${ }^{2}$ Jiangsu Key Laboratory for \\ Premium Steel Material, Technology Center of Nanjing Iron \& Steel Co., Ltd., Nanjing, China
}

The corrosion behavior and mechanism of $\mathrm{PH} 13-8 \mathrm{Mo}$ stainless steel with and without nitric acid passivated film were studied through 5 years of outdoor exposure tests in industry-marine atmospheric environments in Qingdao, by means of morphological observation, weight-loss measurement, X-ray photoelectron spectroscopy (XPS) and Scanning Kelvin Probe (SKP). The results showed that the pre-passivation certainly inhibits the corrosion, but exhibits an obvious limitation of protection period for $\mathrm{PH} 13-8 \mathrm{Mo}$ stainless steel in industrial-marine atmosphere. Compared with bare $\mathrm{PH} 13-8 \mathrm{Mo}$ steel, the number and depth of pitting of pre-passivated steel were reduced, and the average corrosion rate decreased by $14.7 \%$. The reasons of improved corrosion resistance included the higher ratio of $\mathrm{Cr} / \mathrm{Fe}$ and oxide/hydroxide, and the more positive and homogeneous Kelvin voltage potential for the surface of outdoor exposed pre-passivated steel. Meanwhile, the pre-passivation film on the Cr-depleted regions caused by the Cr-rich precipitated phase was preferentially destructed in the atmosphere with $\mathrm{Cl}^{-}$, which decreased the protection period.

Keywords: PH13-8Mo stainless steel, pre-passivated treatment, atmosphere corrosion, pitting, surface potential

\section{INTRODUCTION}

PH13-8Mo is a martensitic age-strengthened stainless steel with a special grade of steel, which has ultra-high strength and toughness while maintaining good plasticity. Because its outstanding mechanical properties and corrosion resistance, as well as its stable performance in high temperature service environments, it is widely favored in the aviation and traditional energy fields (Friedrich and Schumann, 2001; Li et al., 2017). Typical applications are in aerospace connecting fasteners and aircraft landing gear (Imrie, 1970; Munn and Andersson, 1990; Yue et al., 2009). Due to the wide range of aircraft service and complex corrosive environment, especially in industrial marine atmospheres with industrial pollution, high $\mathrm{Cl}^{-}$concentration (Ghods et al., 2010; $\mathrm{Hu}$ et al., 2011; Klapper et al., 2013; Chong and Cheung, 2014) and high humidity characteristics (Carmezim et al., 2005; Zou et al., 2014), resistance of PH13-8Mo stainless steel corrosion is especially important for aircraft life and safety.

There are some studies related to corrosion of stainless steel in atmospheric environment (Lo et al., 2009; Li et al., 2015). The influence of surface treatment of 304L stainless steel on atmospheric corrosion resistance was studied by Wallinder et al. (2003). Button and Simm (1985) revealed the corrosion of 316 stainless steel exposed in different parts for 4 to 30 years. Passivation behavior and 
surface chemistry of 2507 SDSS in acidified artificial seawater have been investigated by Cui et al. (2017). Above literatures revealed that the difference in the composition of the passivation film had a significant effect on the corrosion resistance of stainless steel in the marine atmosphere. It is well-known that passivation films on stainless steel are mainly composed of $\mathrm{Cr}$ and $\mathrm{Fe}$ oxides (Goutier et al., 2011; Escrivà-Cerdán et al., 2013) which play an important role in corrosion resistance. The passivation film automatically forms on the surface of the stainless steel under natural conditions, but the corrosion resistance of the film is limited, especially for martensitic stainless steels containing relatively low chromium and nickel. Therefore, in industry, materials or components requiring corrosion resistance are chemically treated to form a passivation film on the surface (Wang et al., 2012).

Previous studies on PH13-8Mo stainless steel focused on heat treatment, precipitation hardening and its hydrogen embrittlement sensitivity (Munn and Andersson, 1990; Guo et al., 2015; Dalmau et al., 2018). However, there are relatively few studies on the corrosion resistance of pre-passivated PH13-8Mo steel, and especially, there is no report on the effect and limitation of protection period of pre-passivation on pitting behavior of PH13-8Mo steel in long term of real harsh natural environment.

The experiment in this study was carried out in Tuandao Cape, Qingdao, which has a typical industrial-marine atmosphere (Yan et al., 2017). PH13-8Mo stainless steel samples with and without inorganic pre-passivated surface were exposed in Tuandao Cape for 5 years, and the corrosion behaviors of the steel were investigated. The composition and electrochemical characteristics of the pre-passivated layer and corrosion products were analyzed by microscopic analysis, XPS analysis and scanning Kelvin probes. The protective properties of pre-passivated layer and the corrosion mechanism of PH13-8Mo stainless steel were discussed, which is important for improving the environmental adaptability of materials and ensuring the flight safety of aircraft. The results provide not only the selection and route of surface treatment but also boundedness of protection period for aerospace martensitic stainless steel in industrial-marine atmospheric environment.

\section{EXPERIMENTAL}

\section{Materials Preparation}

The experimental PH13-8Mo steel is martensitic precipitation hardening stainless steel with the chemical composition (wt. \%) of $0.055 \mathrm{C}-0.065 \mathrm{Si}-0.046 \mathrm{Mn}-12.42 \mathrm{Cr}-8.14 \mathrm{Ni}-1.14 \mathrm{Al}-$ $2.40 \mathrm{Mo}-0.023 \mathrm{P}$ - 0.020S. PH13-8Mo stainless steel samples were oil quenched after being held at $900^{\circ} \mathrm{C}$ for $1 \mathrm{~h}$, and kept in air for $1 \mathrm{~h}$, then cold treated at $0^{\circ} \mathrm{C}$ for $1 \mathrm{~h}$. Finally, the samples were tempered at $510^{\circ} \mathrm{C}$ for $4 \mathrm{~h}$. The as-prepared samples possessed average yield strength of $1,310 \mathrm{MPa}$, tensile strength of 1,400 $\mathrm{MPa}$ and elongation of $10.8 \%$. The internal microstructure and precipitation phase of the samples were observed by transmission electron microscopy (TEM; FEI TECNAI G20). The TEM samples with diameter of $3 \mathrm{~mm}$ were prepared by grinding, polishing and twin-jet electropolishing.

Figure 1 shows the precipitation phase inside the $\mathrm{PH} 13-8 \mathrm{Mo}$ steel. It can be seen from Figure 1A that the microstructure of the stainless steel is lath martensite and small amount of residual austenite, and the average width of the laths is about $0.2 \mu \mathrm{m}$. These laths contain very high density dislocations, which may be resulted from advancing austenite-martensite boundaries or phase transformation stress (Seetharaman et al., 1981; Kong et al., 2018). A small amount of twins appear inside the matrix shown in Figure 1B. These twins have strict planar boundaries. Further, there are a large number of precipitated phase particles inside the PH13-8Mo steel which was analyzed by TEM, and the results are shown in Figure 2. The precipitated phase is mainly rod-shaped $\mathrm{M}_{23} \mathrm{C}_{6}$ phase with large size and circular NiAl-containing phase.

\section{Passivation Pretreatment and Field Exposure Experiment}

The size of the flat samples of PH13-8Mo steel was $100 \mathrm{~mm}$ $\times 50 \mathrm{~mm} \times 3 \mathrm{~mm}$. Before the pre-passivation treatment, the bare samples were sequentially ground with 2,000 grit $\mathrm{SiC}$ abrasive papers, and then degreased by acetone and ethanol. After the surface treatment, the steel was subjected to passivation treatment, and the passivation agent is $30 \%$ concentrated nitric acid solution. After immersed in the agent for $60 \mathrm{~min}$ at
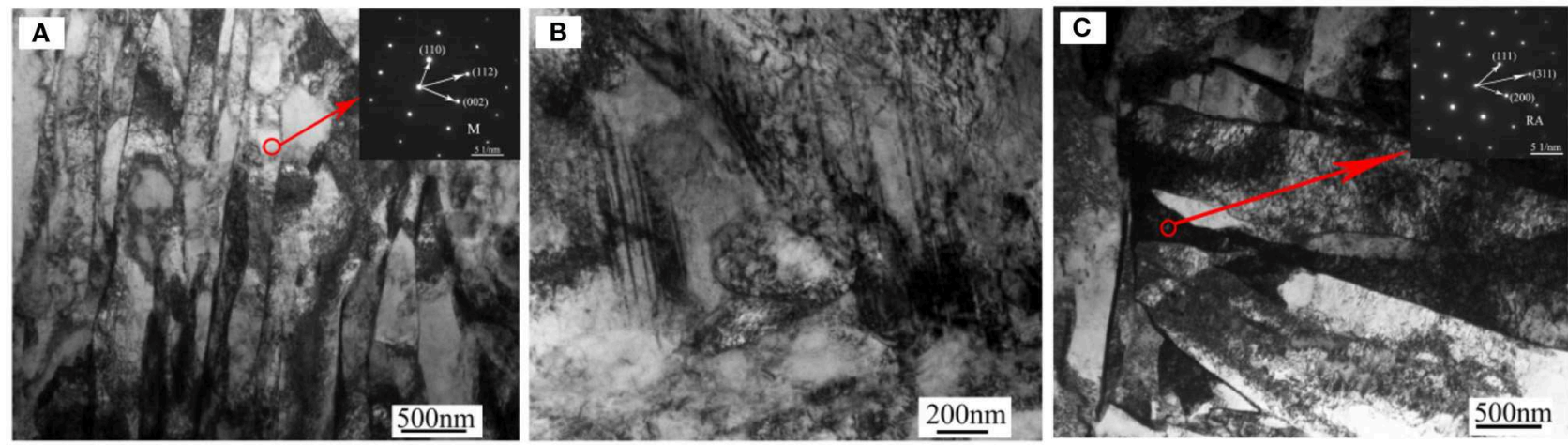

FIGURE 1 | TEM micrographs of PH13-8Mo steel (A) martensitic laths, (B) twins at the grain boundary, (C) residual austenite between martensite laths. M, martensite; RA, residual austenite. 

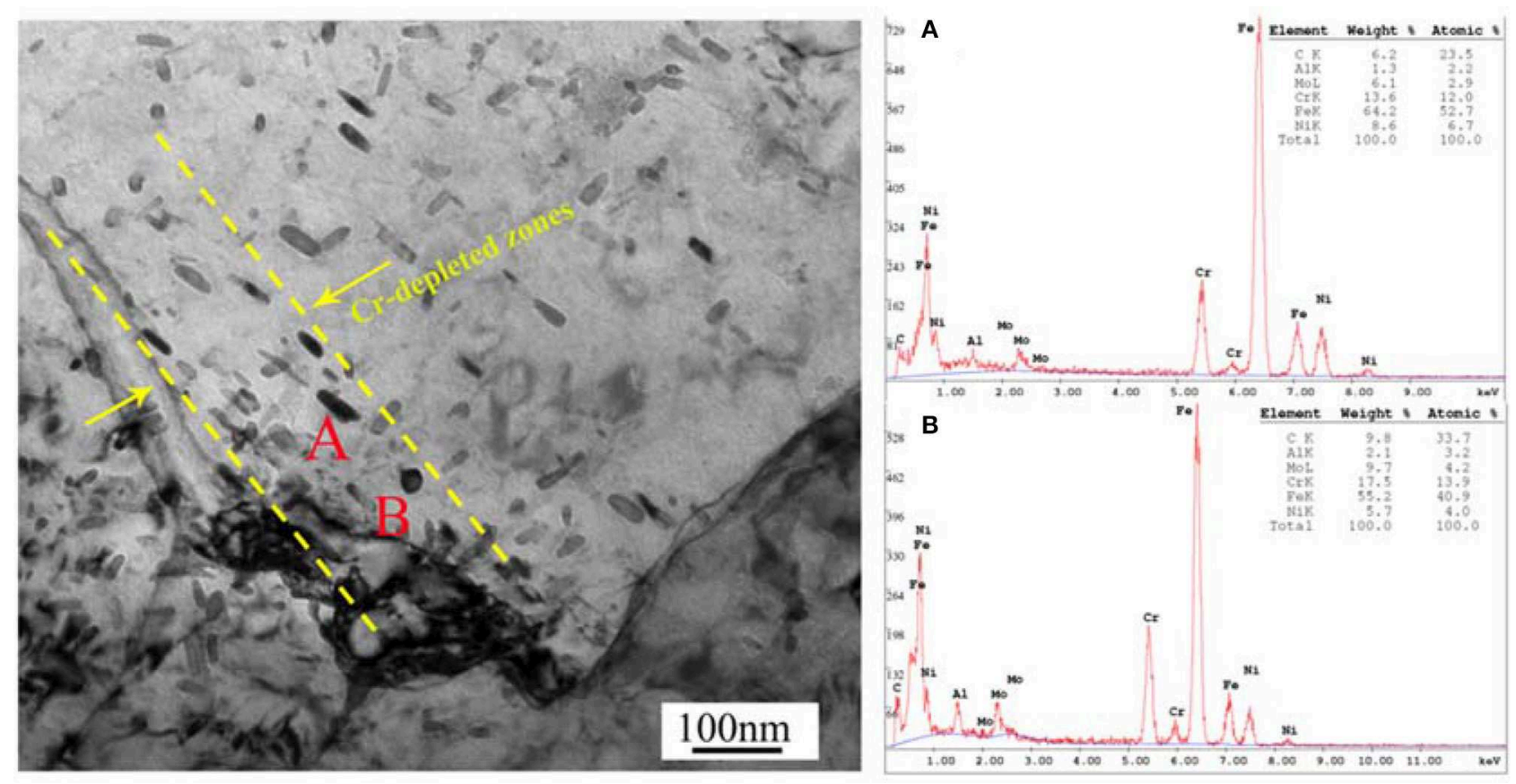

FIGURE 2 | Bright field TEM image showing the morphologies and chemical composition of the precipitates $(\mathbf{A}, \mathbf{B})$.

temperature of $25^{\circ} \mathrm{C}$, the samples were rinsed with distilled water, and then dried at room temperature and placed in a desiccator for use. After the flat samples were cleaned and dried, the original weight of the flat samples was weighed and recorded using an analytical balance with an accuracy of $0.001 \mathrm{~g}$, and then according to "GB 11112-89 Non-ferrous Metal Atmospheric Corrosion Test Method," the outdoor exposure test was carried out in Qingdao Tuandao Cape belonging to the industrial marine atmosphere. Four parallel samples were tested in each experiment, and the exposure duration was 5 years. The environment data of exposure field during the test period are shown in Table 1.

\section{Weight Loss Measurement}

After 5 years of exposure, the corrosion products of the samples were chemically removed by pickling in the solution $(200 \mathrm{~mL}$ nitric acid plus deionized water to make $1,000 \mathrm{~mL}$ solution) for $60 \mathrm{~min}$ at $20^{\circ} \mathrm{C}$ according to $\mathrm{GB} / \mathrm{T} 16545-2015$. The samples were then rinsed with distilled water and dried in air. Then, the samples were weighed to obtain the final weights $\left(W_{1}\right)$. The average corrosion rate after exposure was calculated as follows:

$$
V=\frac{W_{0}-W_{1}}{S t}
$$

where $V$ is the corrosion rate $\left(\mathrm{g} \cdot \mathrm{m}^{-2} \cdot \mathrm{a}^{-1}\right), W_{0}$ was the original weight $(\mathrm{g}), W_{1}$ is the final weight $(\mathrm{g}), S$ is the surface area $\left(\mathrm{m}^{2}\right)$, and $t$ is the exposure time (year).

Corrosion morphologies of the exposed samples with and without passivation pretreatment were observed by scanning electron microscopy (SEM, Quanta 250). The
TABLE 1 | Environmental data during the experiment.

\begin{tabular}{llll}
\hline $\begin{array}{l}\text { Experiment } \\
\text { stations }\end{array}$ & Climate & $\begin{array}{l}\text { Weather factors } \\
\text { (annual average) }\end{array}$ & $\begin{array}{l}\text { Corrosion } \\
\text { concentration } \\
\mathbf{( m g} / \mathbf{1 0 0} \mathbf{~ c m}^{2} \text {.day) }\end{array}$ \\
\hline $36.05^{\circ} \mathrm{N}$, & North & Temperature: & $\mathrm{H}_{2} \mathrm{~S}: 0.0607$ \\
$120.29^{\circ} \mathrm{E}$ & temperate & $12.7^{\circ} \mathrm{C}$ & Sea-salt particles: \\
Altitude: $12 \mathrm{~m}$ & $\begin{array}{l}\text { monsoon } \\
\text { Climate and }\end{array}$ & $\begin{array}{l}\text { Rainfall: } 955.2 \mathrm{~mm} \\
\text { Relative Humidity: }\end{array}$ & $\begin{array}{l}0.5606 \\
\text { Sulfation rate: } \\
\end{array}$ \\
& ocean climate & $74.6 \%$ & 0.3287 \\
\hline
\end{tabular}

elemental composition of the corrosion products was analyzed using EDS. The measurement of the depths of pits and the corresponding morphology observation after rust removal was carried out via a laser confocal microscope. Furthermore, surface element and valence was determined by XPS (X-ray photoelectron spectroscopy).

\section{XPS}

X-ray photoelectron spectroscopy (XPS) was carried out before and after exposure to determine the changes on the surface of the PH13-8Mo. The samples were cleaned ultrasonically in acetone before the measurement. A Thermo ESCALAB 250Xi spectrometer equipped with an $\mathrm{Al} \mathrm{K \alpha} \mathrm{X}$-ray was used for the XPS analysis, using an accelerating voltage of $15 \mathrm{kV}$ and a current intensity of $12 \mathrm{~mA}$. In order to eliminate any perturbation (charge effects, surface state, etc.), a compensation of charges (in situ correction) was applied and the positions were corrected in reference to the $1 \mathrm{~s}$ spectroscopic state of carbon $(h v=$ 
$1,486.6 \mathrm{eV})$. The position of the hydrocarbon $\mathrm{C} 1 \mathrm{~s}$ peak was assumed to be at $284.6 \mathrm{eV}$ and used as an internal standard to determine the binding energy of other photoelectron peaks.
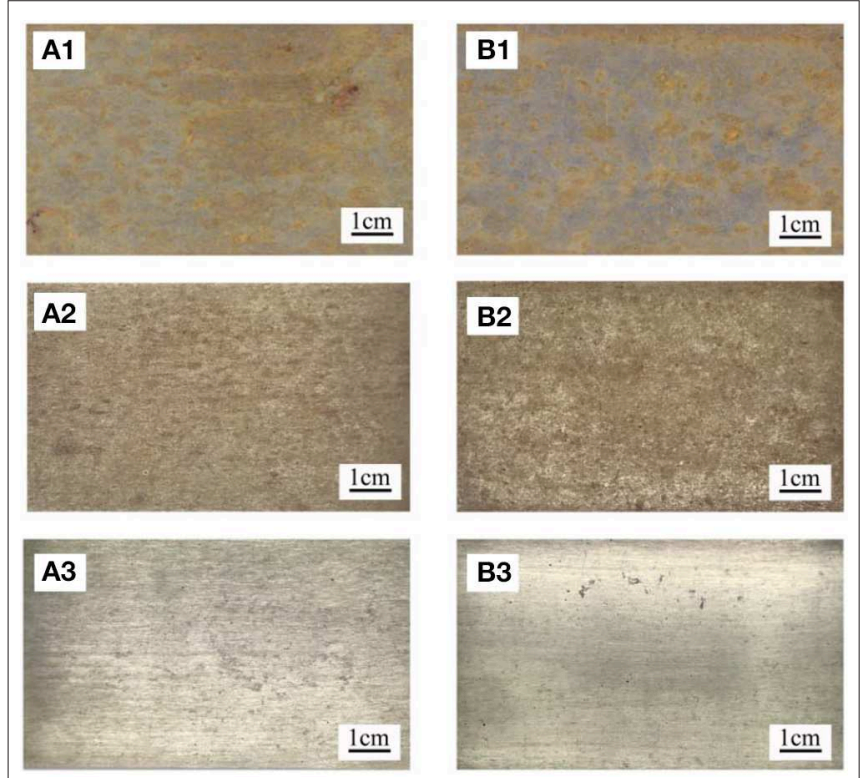

FIGURE 3 | Macroscopic corrosion morphology of each sample (A1-A3) Bare samples exposure for 1 year, exposure for 5 years, and after rust removal of 5 years. (B1-B3) pre-passivated samples exposure for 1 year, exposure for 5 years, and after rust removal of 5 years exposure.
The curve fittings were performed with the software Avantage containing JCPDS files database, which contains the Shirley background subtraction and Gaussian-Lorentzian tail function for better spectra fitting.

\section{Scanning Kelvin Probe (SKP)}

The Kelvin potential distribution of bare and pre-passivated samples after outdoor exposure was further studied by scanning Kelvin probe. The development of local corrosion can be further studied from the surface potential distribution. The surface Volta potentials were measured by a M370 micro-area scanning electrochemical workstation SKP instrument. The scanning area was $1 \mathrm{~mm} \times 1 \mathrm{~mm}$, and the amplitude was $50 \mu \mathrm{m}$. The probe was a tungsten filament, and the working distance of the probe to the surface of the sample was $100 \pm 3 \mu \mathrm{m}$. The test temperature is controlled at an ambient $\left(25^{\circ} \mathrm{C}\right)$, relative humidity is $50 \%$.

The principle of Scanning Kelvin Probe is to detect the electron work function [surface work function $\phi_{\mathrm{M}}$, Equation (1)] of the metal surface. The basic properties of the metal itself are defined as the negative value of the actual potential ae of the metal inside the metal, and $\phi \mathrm{M}$ is equal to the minimum work done to get the electron out of its Fermi level and transfer it to a point outside the metal surface (e.g., in the air), so it consists of two parts: the chemical potential of electron $\mu$ e and the potential drop XM across the metal/air section. If the metal surface has a rust layer or a coating, it will increase the voltage to be applied by the excited electrons, causing the surface Kelvin potential to drop. As to PH13-8Mo stainless steel, the electron escapes through a plurality of interfaces from the substrate-passivation
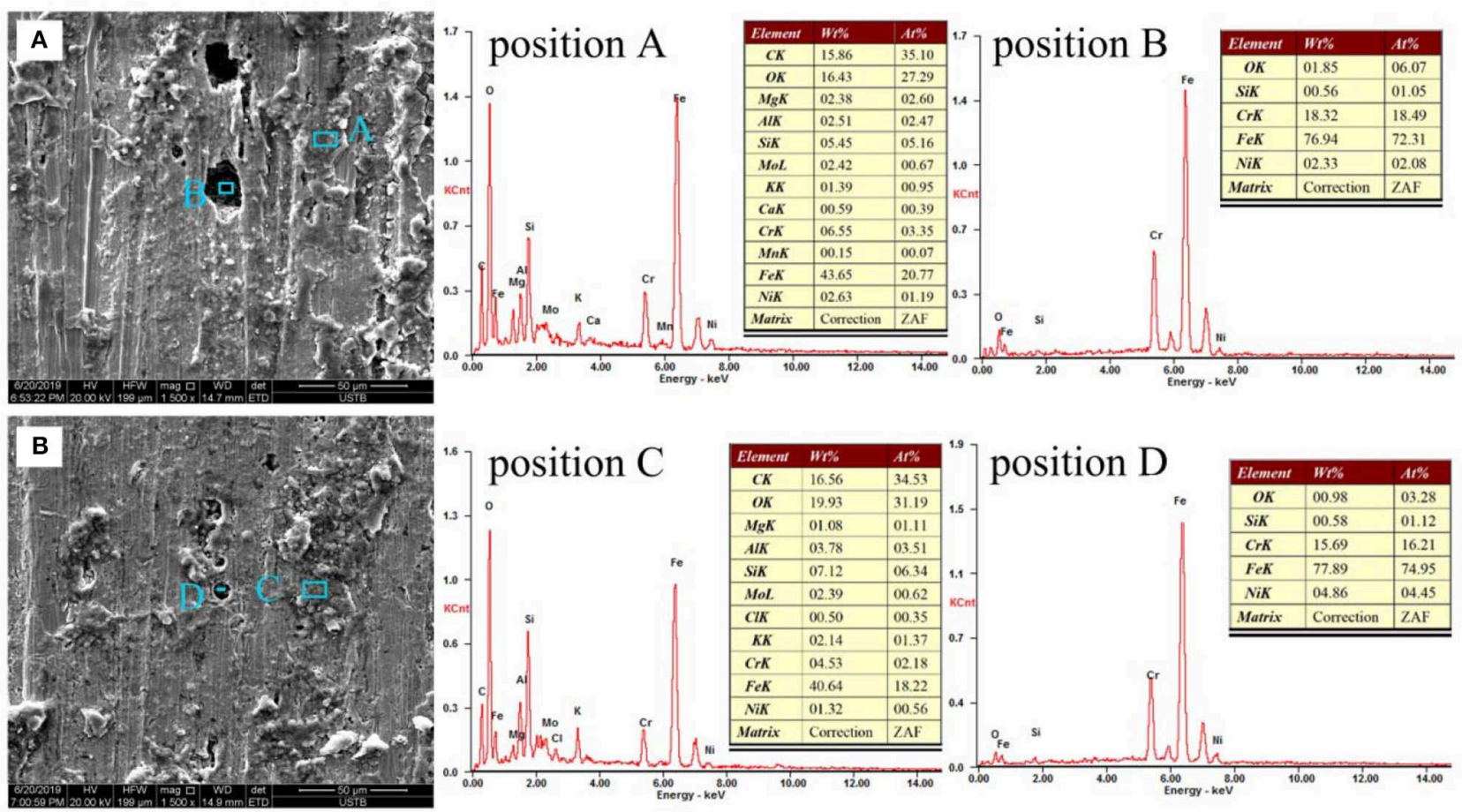

FIGURE 4 | The microscopic morphologies and EDS analysis of the (A) Bare sample; (B) Pre-passivated sample after 5 years exposure. 

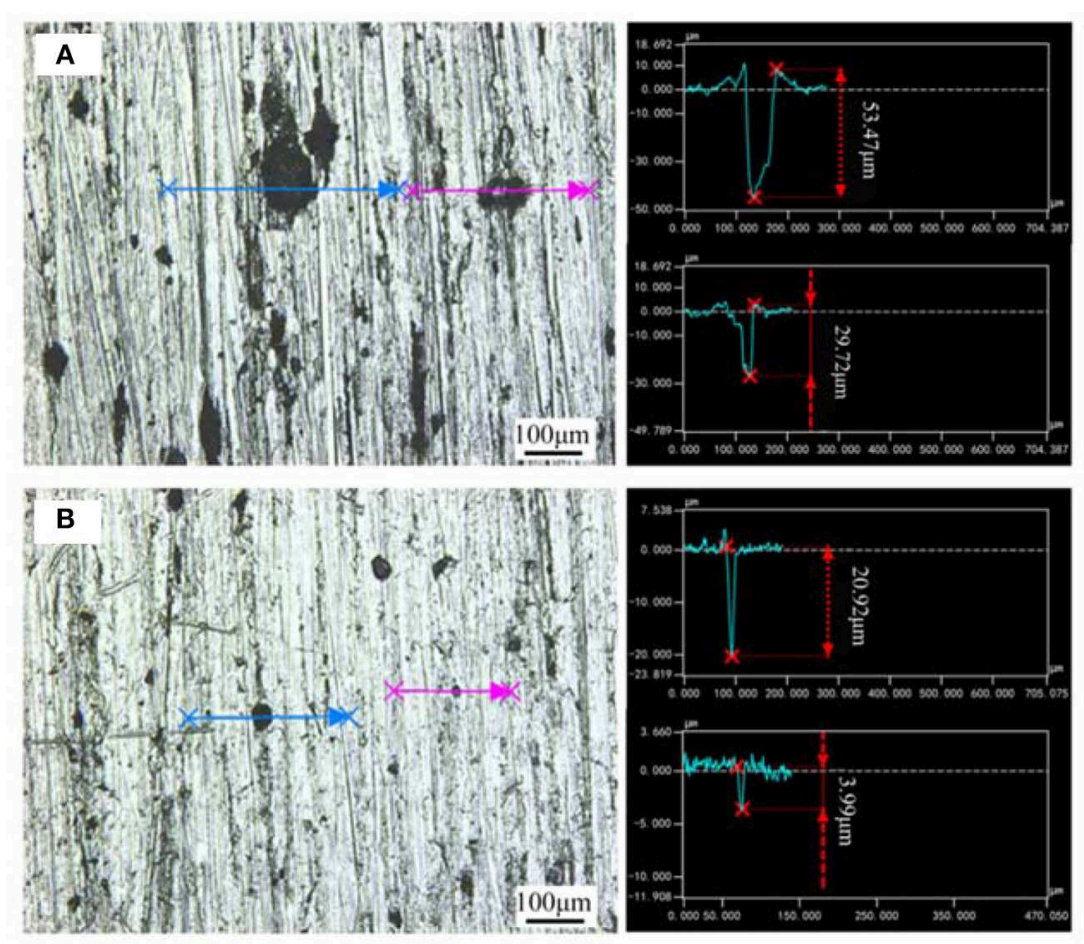

FIGURE 5 | Microscopic morphologies and the corresponding pit depth of (A) Bare sample; (B) Pre-passivated sample after the rust removal.
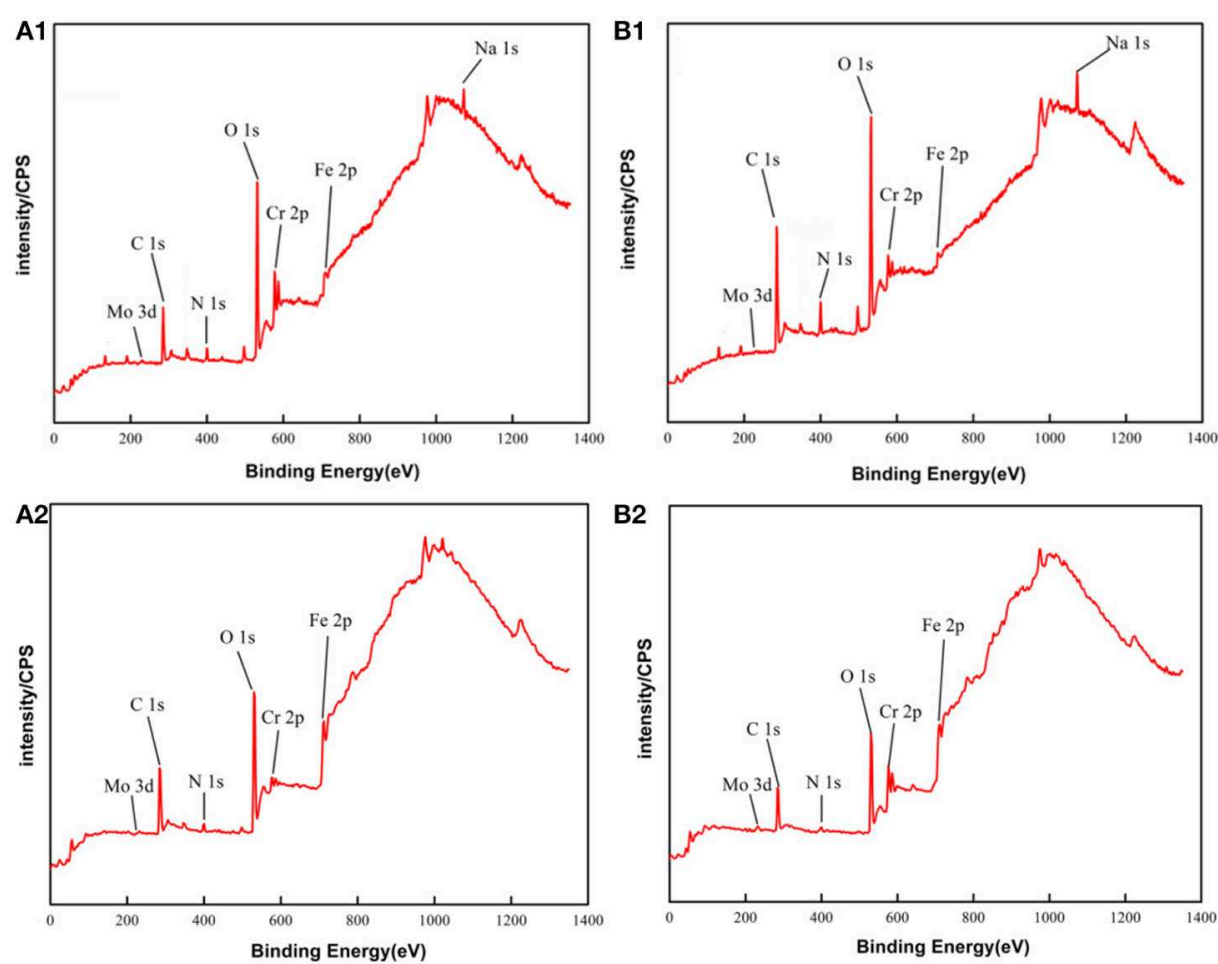

FIGURE 6 | XPS survey spectrum of PH13-8Mo stainless steel: (A1,B1) Bare and pre-passivated sample before exposure; (A2,B2) Bare and pre-passivated sample after 5 year exposure. 
film-corrosion product layer-air. The actually measured electron emission work is shown in Equation (2), where $\beta 1, \beta 2, \beta 3$, $q 1, q 2, q 3$, and $C 1, C 2, C 3$ is the potential drops, charges, and capacitances of the three interfaces, respectively (Merl et al., 2004). The relationship between the electronic properties of the passivation film and the pitting potential can be found in the literature (Nazarov and Thierry, 2007).

$$
\begin{gathered}
\Phi_{M}=-a_{e}=-\mu_{e}+e X_{M} \\
\frac{\Phi_{\mathrm{EXP}}}{e}=\frac{\Phi_{M}}{e}+\beta_{1}+\beta_{2}+\beta_{3}=\frac{\Phi_{M}}{e}+\frac{q_{1}}{C_{1}}+\frac{q_{2}}{C_{2}}+\frac{q_{3}}{C_{3}}
\end{gathered}
$$

In order to further characterize the surface Kelvin potential distribution of the samples, Gaussian fitting analysis is performed on the test results; the fitting formula is:

$$
y=y_{0}+\frac{A}{\sigma \sqrt{2 \pi}} \exp \left(-\frac{(x-\mu)^{2}}{2 \sigma^{2}}\right)
$$

Where $\mu$ is the expected value, i.e., the focus position of the potential distribution; $\sigma$ is the standard deviation of the distribution of the Gaussian analysis (i.e., the representative dispersion of the potential distribution; the larger the value, the larger the dispersion potential distribution) (Wang et al., 2019).

\section{RESULTS AND DISCUSSION}

\section{Weight Loss and Corrosion Rate}

The corrosion rates of bare and pre-passivated treatment of PH13-8Mo stainless steel after exposure in Qingdao were 4.07 $\mathrm{g} \cdot \mathrm{m}^{-2} \cdot \mathrm{a}^{-1}$ and $3.47 \mathrm{~g} \cdot \mathrm{m}^{-2} \cdot \mathrm{a}^{-1}$, respectively. It can be obviously seen that the corrosion resistance of $\mathrm{PH} 13-8 \mathrm{Mo}$ stainless steel was well. Compared with the bare samples, the average corrosion rate of the pre-passivated samples after 5 years exposure test decreased by $14.7 \%$. The corrosion resistance of the PH13-8Mo stainless steel pre-passivated with concentrated nitric acid was stronger than that of the bare steel, the pre-passivation film has a certain protective effect on the $\mathrm{PH} 13-8 \mathrm{Mo}$ stainless steel matrix in the industrial marine atmosphere.

\section{Surface Morphologies and Corrosion Product Analysis}

Figure 3 shows the macroscopic morphology of exposed PH13$8 \mathrm{Mo}$ stainless steel sheets of bare and pre-passivated samples exposed for 1 and 5 years before and after rust removal. For the 1 year exposure samples, both bare and pre-passivated samples depicted significant pitting characteristics, and most
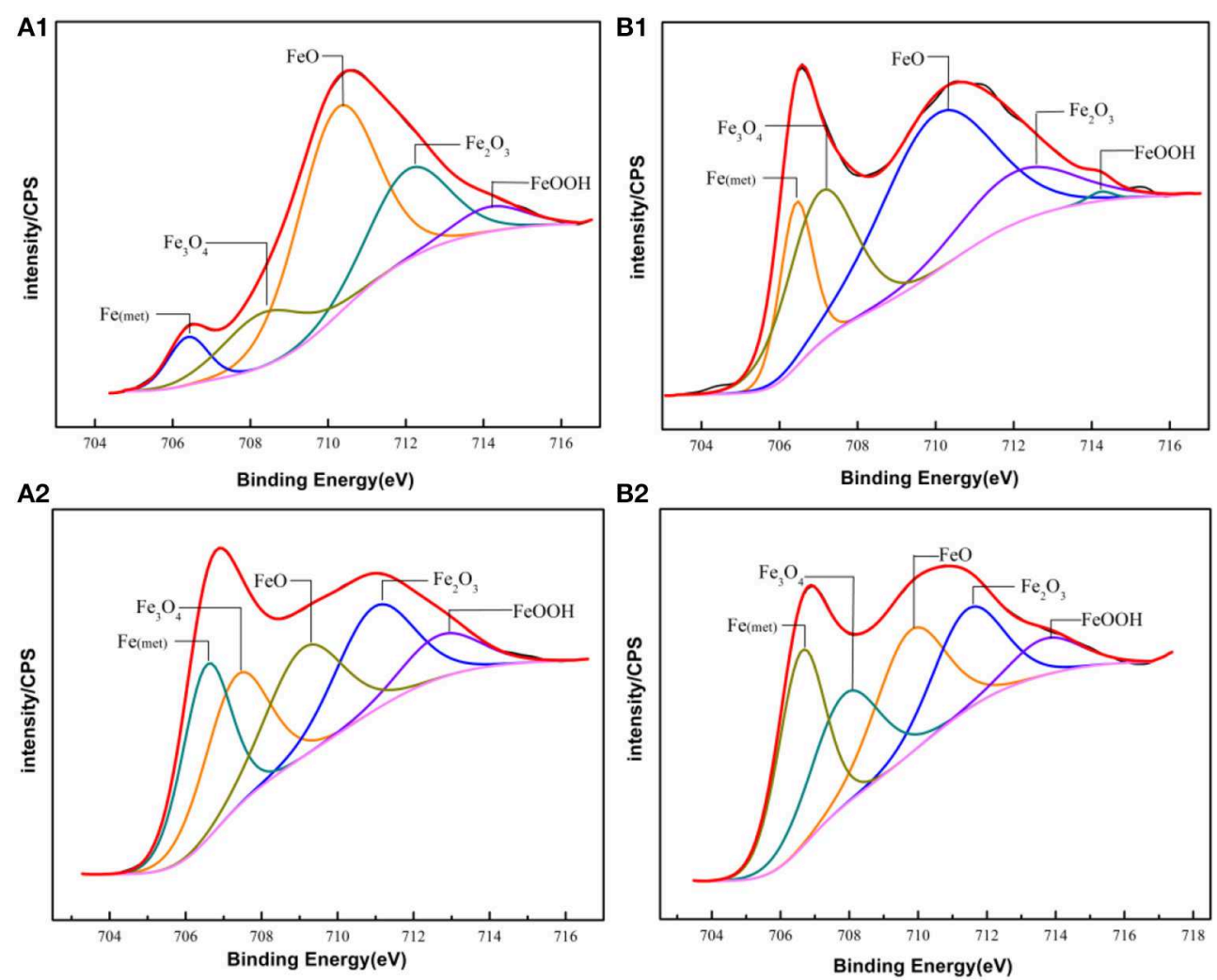

FIGURE 7 | Experimental and fitted narrow XPS spectra of Fe 2p $p_{3 / 2}$ of the surface film of (A1,B1) Bare and pre-passivated sample before exposure; (A2,B2) Bare and pre-passivated sample after 5 year exposure. 
areas of the bare sample surface were covered with corrosion products, while the corroded area of the pre-passivated sample was far less, and the metallic luster was visible in local positions. After the 5 year exposure, the overall area of the bare samples lost the silver-white metallic luster, and were covered by the reddish brown corrosion products. In addition, the thickness of the rust layer was uneven as some rust layer fell off, and small dots and flakes were distributed on some locations. As for the pre-passivated sample, the surface was also completely covered by the rust layer, and the macroscopic morphology was almost the same as the bare sample. Specially, the rust layer was mainly distributed on the edge of the samples, which led to the accumulation of thin electrolyte film at the edge and thus induced the more severe corrosion. After rust removal, large amounts of pits were observed on both bare and pre-passivated samples, while the number of pits on the pre-passivated was less and the corresponding sizes were smaller, which indicated the prepassivation effectively weakened the pitting of the steels. Overall, in the long-term industrial-marine atmospheric environment, the pre-passivation treatment limitedly delayed the occurrence of the pitting and uniform corrosion, but did not alter the corrosion mechanism of the steels.

The microscopic morphologies of the exposed stainless steel plate and the chemical compositions of the rust layer and pits were shown in Figure 9. After 5 year exposure, the surface of bare sample was covered by lots of corrosion products which were irregularly deposited in local areas. In addition, the surface of the bare sample exhibited typical pitting characteristics, and the diameters of the pits varied from several micrometers to about $20 \mu \mathrm{m}$. While for the pre-passivated samples, there were fewer corrosion products covering the surface of the sample, and the number of the pits significantly decreased. Furthermore, the diameters of the pits measured were within $10 \mu \mathrm{m}$, which indicated that the pre-passivation was unable to change the corrosion types, but it greatly inhibited the initiation and propagation of the uniform and pitting corrosion.

It was well-acknowledged that the surface active sites such as inclusions, precipitates and the weak passive film region, were generally assigned as the pitting nucleation locations (Vignal et al., 2014). In PH13-8Mo stainless steel, there were a large amount of Cr-rich $\mathrm{M}_{23} \mathrm{C}_{6}$ precipitates, which induced the emergence of the $\mathrm{Cr}$-depleted zones around the precipitates (Luo et al., 2018), as shown in Figure 2. The surface passive film over the Cr-depleted regions was known to be weak and thus led to the preferential attack (Ryan et al., 2002; Bonagani et al., 2018) by the high concentration of the chloride ion in the industrial-marine atmosphere, which created a priority for the pitting nucleation. Therefore, both the chloride-containing environment and the Cr-rich precipitates played an important role in the initiation of the pitting corrosion. As the exposure time

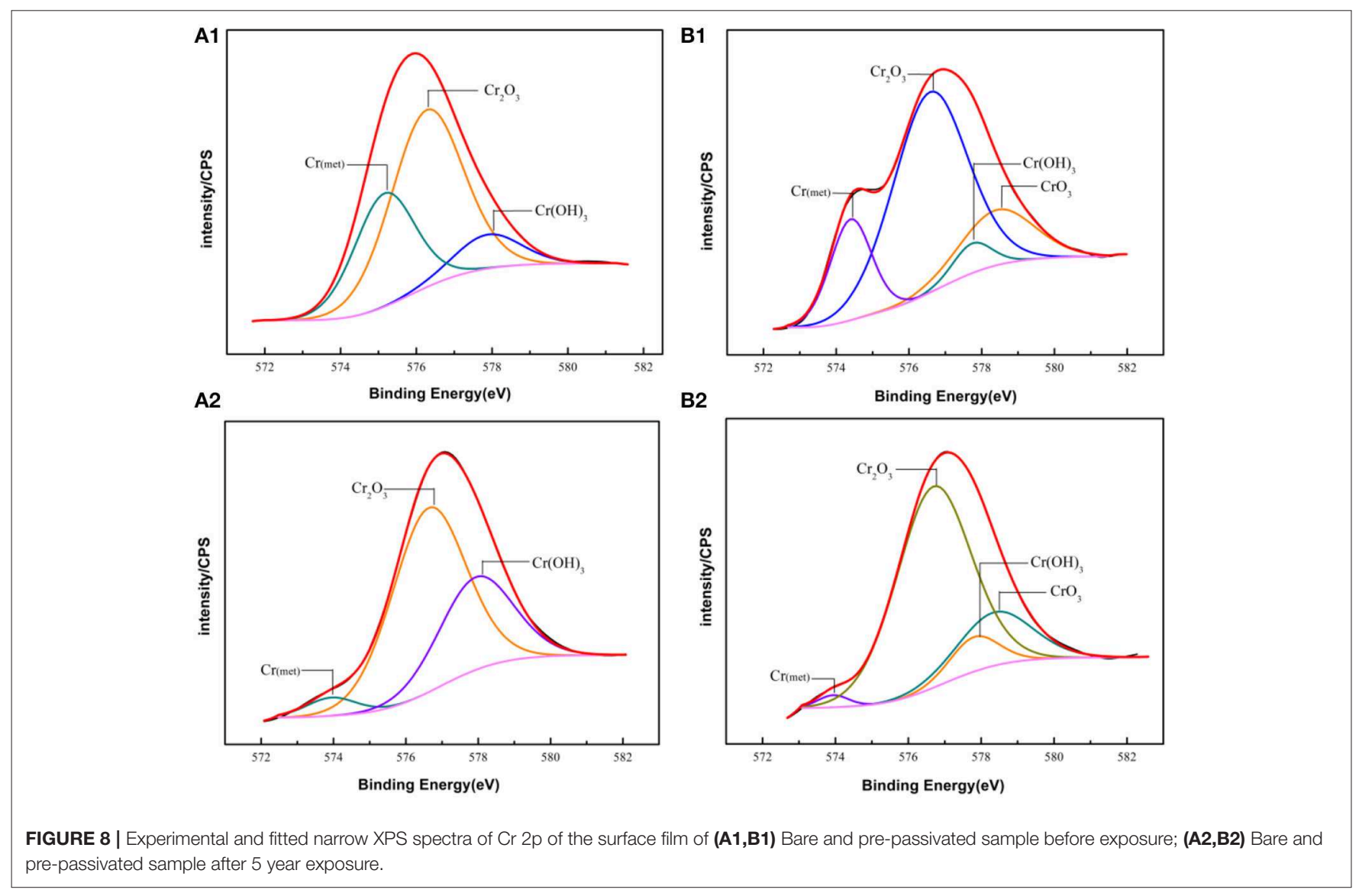


increased, autocatalytic reaction of occlusion cell in the pits and the penetration of the corrosive medium caused the corrosion inside the pits to propagate. From Figure 4, in both bare and pre-passivated stainless steel, the surface corrosion products were mainly composed of $\mathrm{Fe}, \mathrm{O}, \mathrm{Si}, \mathrm{Cr}, \mathrm{Ni}, \mathrm{Mo}$, while Mo element was not detected in the pitting corrosion products. Mo element had the lower diffusion rate than those of $\mathrm{Cr}$ and Ni elements (Jin and Atrens, 1988) that led to the difference of the surface and pitting corrosion products in Figure 4.

Figure 5 showed the surface morphologies of the samples after rust removal and the corresponding depths of the pits. As shown in Figure 5A, the pits on the surface of the bare sample were large and connected into pieces, which tended to be denuded, and the depths could be as deep as $50 \mu \mathrm{m}$. While, after pre-passivation treatment, the area and depth of pits significantly decreased compared with the bare sample, and the surface was also relatively flat, which also supported the view that the pre-passivated treatment weakened the propagation of the uniform and pitting corrosion but could not ultimately prevent the occurrence of the corrosion.

\section{The XPS Analysis}

The main compositions of the surface of PH13-8Mo stainless steel before and after 5 year exposure were determined by XPS. The XPS survey spectrums of the bare and pre-passivated samples are shown in Figure 6. The high-resolution images of
Cr $2 \mathrm{p}_{3 / 2}$, Fe $2 \mathrm{p}_{3 / 2}$, Mo 3d, and O1s were presented in Figures 710, and Table 2 listed the corresponding binding energies of the obtained deconvolution from XPS spectra. As shown in Figure $7 \mathrm{~A}$, the $\mathrm{Fe} 2 \mathrm{p}_{3 / 2}$ spectra of the bare samples could be deconvoluted into several peaks representing the metallic state $\mathrm{Fe}_{\text {(met) }}(706.55 \mathrm{eV})$, the bivalent $\left(\mathrm{Fe}^{2+}\right)$ and trivalent $\left(\mathrm{Fe}^{3+}\right)$ species. From the Figure $\mathbf{7 B 1}$, the relative peak heights of $\mathrm{Fe}_{3} \mathrm{O}_{4}(707.5 \mathrm{eV})$ and $\mathrm{Fe}_{2} \mathrm{O}_{3}(712.1 \mathrm{eV})$ indicate that $\mathrm{Fe}_{3} \mathrm{O}_{4}$ and $\mathrm{Fe}_{2} \mathrm{O}_{3}$ were the primary iron oxidized species in the passive film before exposure. However, after 5 years of exposure, the surface of the bare sample and the pre-passivated sample were covered with corrosion products, and the composition of the $\mathrm{Fe}$ compound was not different. The relative peak heights of $\mathrm{Fe}_{3} \mathrm{O}_{4}(707.34 \mathrm{eV}), \mathrm{FeO}(709.11 \mathrm{eV}), \mathrm{Fe}_{2} \mathrm{O}_{3}(710.96 \mathrm{eV})$, $\mathrm{FeOOH}(712.70 \mathrm{eV})$ indicated that the corrosion products on the surface of the samples were iron oxide and oxyhydroxide. The anodic process was characterized by the dissolution of iron (Chen et al., 2009):

$$
\begin{array}{r}
\mathrm{Fe}-2 \mathrm{e}^{-} \rightarrow \mathrm{Fe}^{2+}, \\
\mathrm{Fe}^{2+}+2 \mathrm{OH}^{-} \rightarrow \mathrm{Fe}(\mathrm{OH})_{2}
\end{array}
$$

$\mathrm{Fe}(\mathrm{OH})_{2}$ would be oxidized to $\mathrm{FeOOH}$ and $\mathrm{Fe}_{3} \mathrm{O}_{4}$, while $\mathrm{FeOOH}$ was unstable and would continue to be oxidized, the reactions were as follow (Hu et al., 2011):
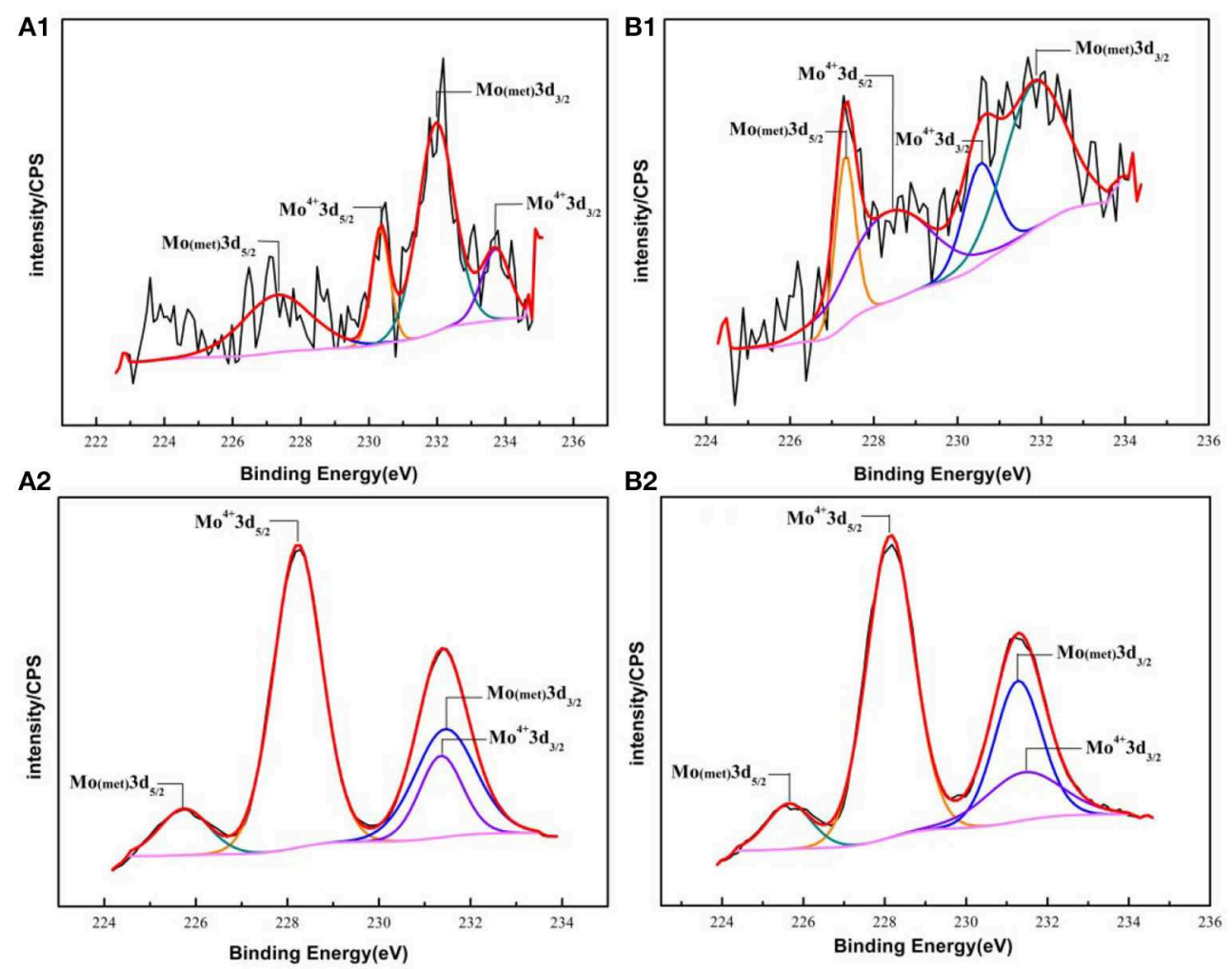

FIGURE 9 | Experimental and fitted narrow XPS spectra of Mo 3d of the surface film of (A1,B1) Bare and pre-passivated sample before exposure; (A2,B2) Bare and pre-passivated sample after 5 year exposure. 

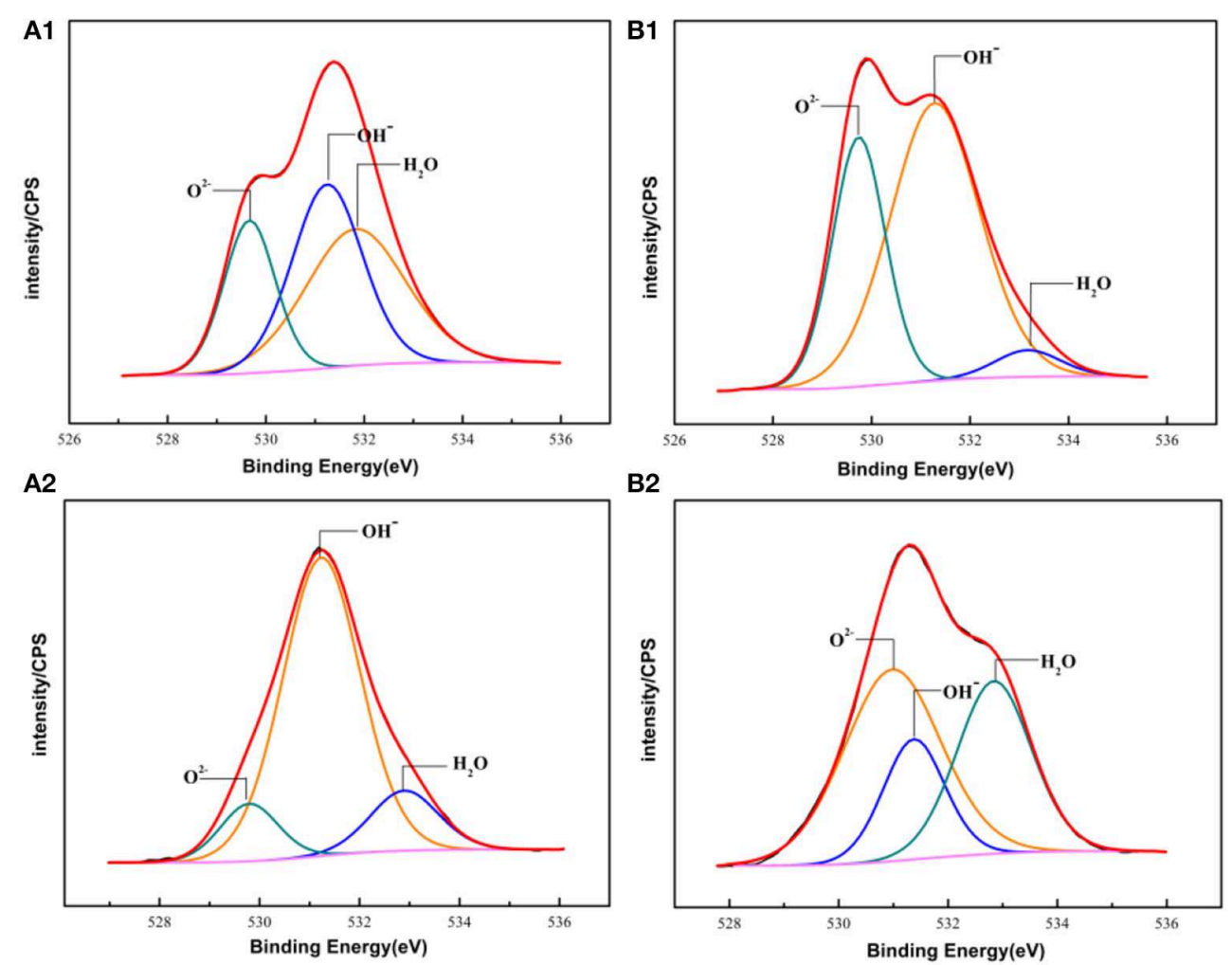

FIGURE 10 | The XPS spectra of O 1s of the passive films formed on PH13-8Mo stainless steel surface (A1,B1) Bare and pre-passivated sample before exposure; (A2,B2) Bare and pre-passivated sample after 5 year exposure.

$$
\begin{array}{r}
4 \mathrm{Fe}(\mathrm{OH})_{2}+\mathrm{O}_{2} \rightarrow 4 \mathrm{FeOOH}+2 \mathrm{H}_{2} \mathrm{O} \\
2 \mathrm{FeOOH} \rightarrow \mathrm{Fe}_{2} \mathrm{O}_{3}+3 \mathrm{H}_{2} \mathrm{O} \\
6 \mathrm{Fe}(\mathrm{OH})_{2}+\mathrm{O}_{2} \rightarrow 2 \mathrm{Fe}_{3} \mathrm{O}_{4}+6 \mathrm{H}_{2} \mathrm{O}
\end{array}
$$

The fitting results of the $\mathrm{Cr} 2 \mathrm{p}$ revealed that there exist four peaks representing metallic state $\mathrm{Cr}_{(\text {met })}(573.94 \mathrm{eV})$, $\mathrm{Cr}_{2} \mathrm{O}_{3}(576.62 \mathrm{eV}), \mathrm{CrO}_{3}(577.93 \mathrm{eV}), \mathrm{Cr}(\mathrm{OH})_{3}(587.18 \mathrm{eV})$. The intensities of the $\mathrm{Cr}(\mathrm{OH})_{3}$ and $\mathrm{Cr}_{2} \mathrm{O}_{3}$ states are apparently higher than that of the $\mathrm{Cr}(\mathrm{met})$ and these oxidized components were the primary components of the passive film in stainless steel (Luo et al., 2011). Compared with the bare sample, $\mathrm{Cr}^{6+}$ was detected in the passive film, which might be introduced via the pre-passivation process (Cheng et al., 2009). The ratio of $\mathrm{Cr}_{2} \mathrm{O}_{3}$ and $\mathrm{Cr}(\mathrm{OH})_{3}$ decreased after 5 years exposure, but the content of $\mathrm{CrO}_{3}$ was relatively stable. In addition, a relatively low intensity Mo 3d spectra was recorded because of the oxidation states of the Mo 3d region overlap, the curve fitting becomes complicated to achieve the spectra owing to the almost similar energy levels of Mo $3 \mathrm{~d}_{3 / 2}$ and Mo $3 \mathrm{~d}_{5 / 2}$. The signal intensity of $\mathrm{Mo}^{4+}$ $(228.40 \mathrm{eV}, 231.40 \mathrm{eV})$ increased, which indicated that the prepassivation enhanced the enrichment of Mo and further made the passive film much denser (Kraack et al., 1995; Rodriguez et al., 2018). The addition of Mo into stainless steel has a significant effect on promoting the enrichment of $\mathrm{Cr}$ in the passive film
TABLE 2 | The binding energies of the primary compounds of the PH13-8Mo

\begin{tabular}{|c|c|c|}
\hline Element & Peak & Species/Binding energy (eV) \\
\hline $\mathrm{Fe}$ & $2 p_{3 / 2}$ & $\begin{array}{l}\mathrm{Fe}_{(\text {met })} / 706.7 ; \mathrm{Fe}_{3} \mathrm{O}_{4} / 707.8 ; \mathrm{FeO} / 709.4 ; \\
\mathrm{Fe}_{2} \mathrm{O}_{3} / 710.9 ; \mathrm{FeOOH} / 711.8\end{array}$ \\
\hline $\mathrm{Cr}$ & $2 \mathrm{p}_{3 / 2}$ & $\begin{array}{l}\mathrm{Cr}_{(\mathrm{met})} / 574.1 ; \mathrm{Cr}_{2} \mathrm{O}_{3} / 576.7 \\
\mathrm{Cr}(\mathrm{OH})_{3} / 577.8 ; \mathrm{CrO}_{3} / 578.4\end{array}$ \\
\hline \multirow[t]{2}{*}{ Mo } & $3 d_{5 / 2}$ & $\mathrm{Mo}_{\text {(met) }} / 225.7 ; \mathrm{Mo}^{4+} / 228.2$ \\
\hline & $3 d_{3 / 2}$ & $\mathrm{Mo}_{(\text {met }} / 231.4 ; \mathrm{Mo}^{4+} / 231.5$ \\
\hline $\mathrm{O}$ & $1 \mathrm{~s}$ & $\mathrm{O}^{2-} / 530.2 ; \mathrm{OH}^{-} / 531.2 ; \mathrm{H}_{2} \mathrm{O} / 532.9$ \\
\hline
\end{tabular}
stainless steel passive film and corrosion products obtained from XPS spectra deconvolution.

and thus prolonged the induction period in $\mathrm{Cl}^{-}$concentrated environment (Sugimoto and Sawada, 1977; Li et al., 2017).

For the pre-passivated samples, the $\mathrm{Fe} 2 \mathrm{p}_{3 / 2}$ spectra could also be separated into three constituent peaks representing the metallic state $\mathrm{Fe}_{\text {(met) }}(706.61 \mathrm{eV})$, the bivalent $\left(\mathrm{Fe}^{2+}\right)$ and trivalent $\left(\mathrm{Fe}^{3+}\right)$ species, and the relative peak heights of $\mathrm{Fe}_{3} \mathrm{O}_{4}(707.90 \mathrm{eV}), \mathrm{FeO}(709.80 \mathrm{eV}), \mathrm{Fe}_{2} \mathrm{O}_{3}(711.50 \mathrm{eV}), \mathrm{FeOOH}$ $(713.70 \mathrm{eV})$ were a little different from the bare sample. The intensities of iron oxide and oxhydroxide were lower, which attributed to the fewer corrosion products on the surface than those of the bare sample. For the Cr $2 p$ spectra, there exist six 
constituent peaks representing metallic state $\mathrm{Cr}_{(\text {met })}(574.20 \mathrm{eV})$, $\mathrm{Cr}_{2} \mathrm{O}_{3}(576.70 \mathrm{eV}), \mathrm{Cr}(\mathrm{OH})_{3}(577.40 \mathrm{eV})$, and $\mathrm{CrO}_{3}(578.30 \mathrm{eV})$. In addition, the concentration of the $\mathrm{Cr}(\mathrm{OH})_{3}$ became less, while the content of $\mathrm{Cr}_{2} \mathrm{O}_{3}$ increased. Meanwhile, a difference was also displayed in the Mo $3 \mathrm{~d}$ spectrum, however, the Mo and Mo oxidized species were little difference after exposure.

The oxygen species in the passive film acted as connecting metal ions, which were mainly $\mathrm{O}^{2-}, \mathrm{OH}^{-}$. Figure 10 showed the core-level spectra of the surface film formed on the bare and pre-passivation samples in the $\mathrm{O} 1 \mathrm{~s}$ region. The $\mathrm{O} 1 \mathrm{~s}$ spectra could be divided into three components, $\mathrm{O}^{2-}(529.73 \mathrm{eV}), \mathrm{OH}^{-}$ $(531.22 \mathrm{eV})$ and $\mathrm{H}_{2} \mathrm{O}(532.93 \mathrm{eV})$ in the bare sample, and $\mathrm{O}^{2-}$, $\mathrm{OH}^{-}$and $\mathrm{H}_{2} \mathrm{O}$ in the pre-passivation sample. Furthermore, it could be seen that $\mathrm{O}^{2-}$ was the primary constituent of the passive film and corrosion products, which corresponded to the formation of $\mathrm{Cr}_{2} \mathrm{O}_{3}, \mathrm{Fe}_{2} \mathrm{O}_{3}, \mathrm{FeO}$, and $\mathrm{MoO}_{2}$. While the $\mathrm{OH}^{-}$ was also the primary constituent which corresponded to the formation of $\mathrm{Cr}(\mathrm{OH})_{3}$ and $\mathrm{FeOOH}$. The fraction of $\mathrm{Cr}$, Fe oxides and hydroxides and the $\mathrm{Cr} / \mathrm{Fe}$ ratio (at. \%) in the passive films of the both samples were listed in Table 3. The concentration of the $\mathrm{Fe}$ (met) and $\mathrm{Cr}$ (met) decreased sharply after 5 year exposure, which also illustrated that the surface suffered from corrosion and the surface was covered with corrosion products. Previous studies have illustrated that the presence of hydroxides in passive films was detrimental to localized corrosion resistance (Clayton and $\mathrm{Lu}, 1986)$. In this work, it could be found that the prepassivated sample contained more oxides and less hydroxide than that of the bare sample, which reflected that the pre-passivation treatment decreased the fraction of the hydroxide in the passive film and thus enhanced the pitting resistance of the PH13-8Mo stainless steel.

In addition, a large number of researches reported that the repassivition of stainless steel was mainly due to the maintenance of a certain $\mathrm{Cr} / \mathrm{Fe}$ ratio (at \%) in its passivation film (Ryan et al., 2002; Phadnis et al., 2003, Devaux et al., 1994), and the enrichment of $\mathrm{Cr}$ enhanced the stability and corrosion resistance of the passivation film, which resulted in a lower passive current density (Lv et al., 2016). Therefore, it could be found that the $\mathrm{Cr} / \mathrm{Fe}$ ratio of the bare sample was $\sim 3.54$, while it was 4.16 of the pre-passivated sample, which indicated that the prepassivated treatment could significantly increase the $\mathrm{Cr} / \mathrm{Fe}$ ratio of the passive film on the PH13-8Mo stainless steel, and thus

TABLE 3 | The fraction of $\mathrm{Cr}$ and Fe in the surface of the PH13-8 Mo stainless steel.

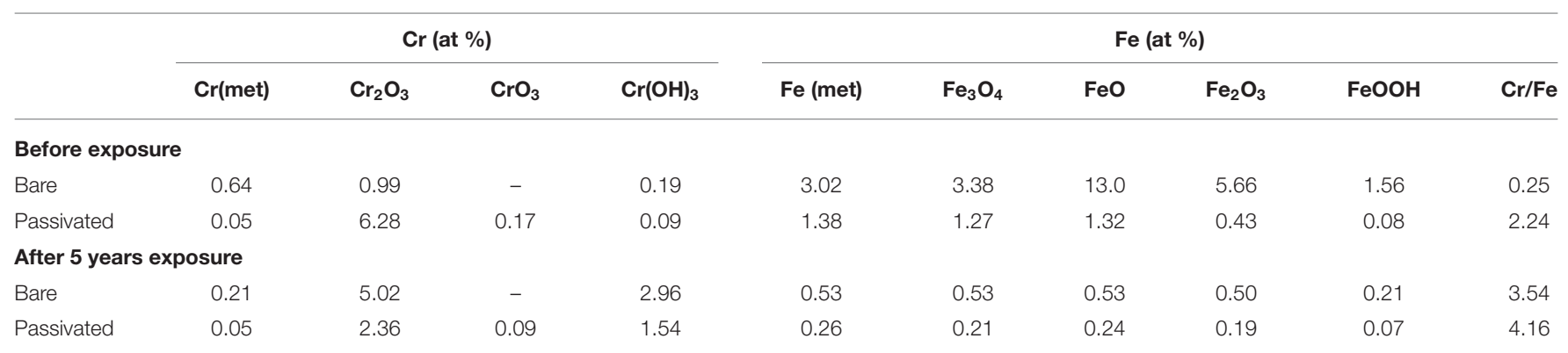
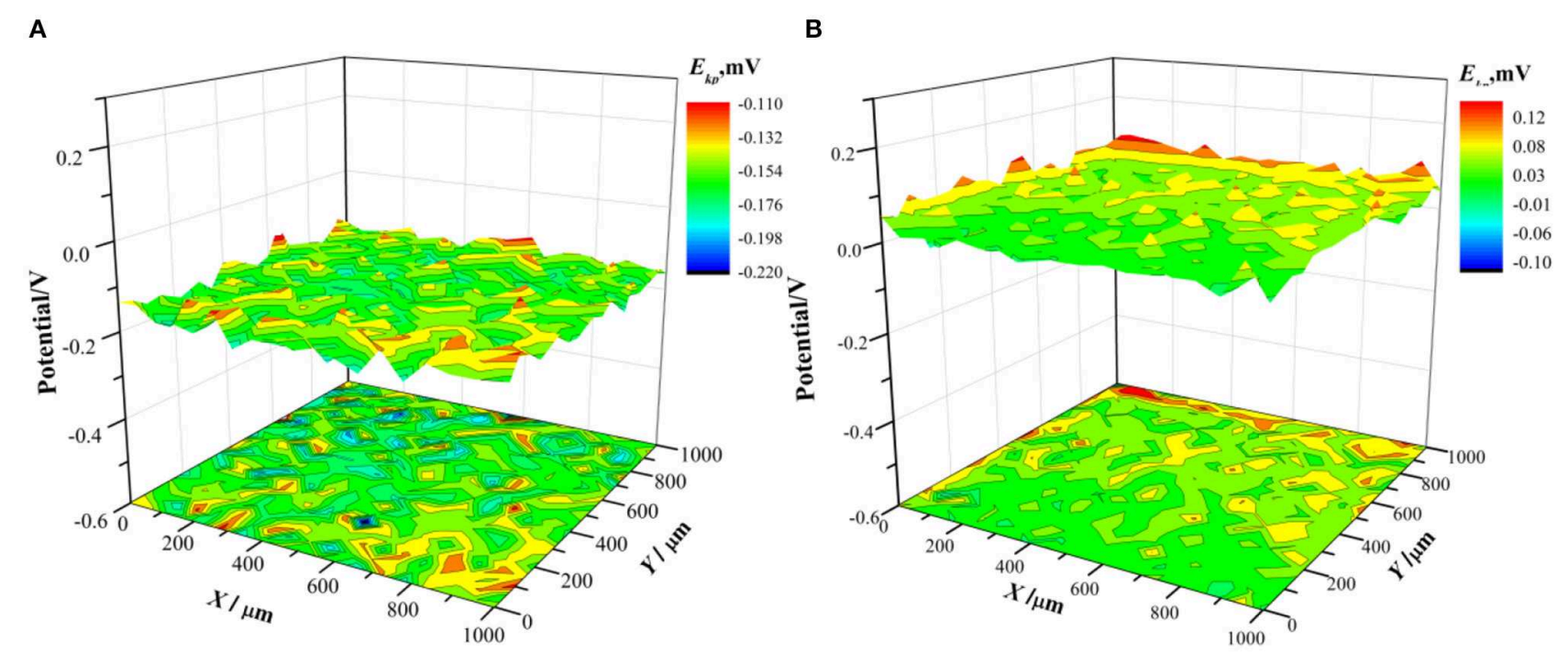

FIGURE 11 | Surface Kelvin potential distribution after 5 year exposure (A) bare sample; (B) pre-passivated sample. 

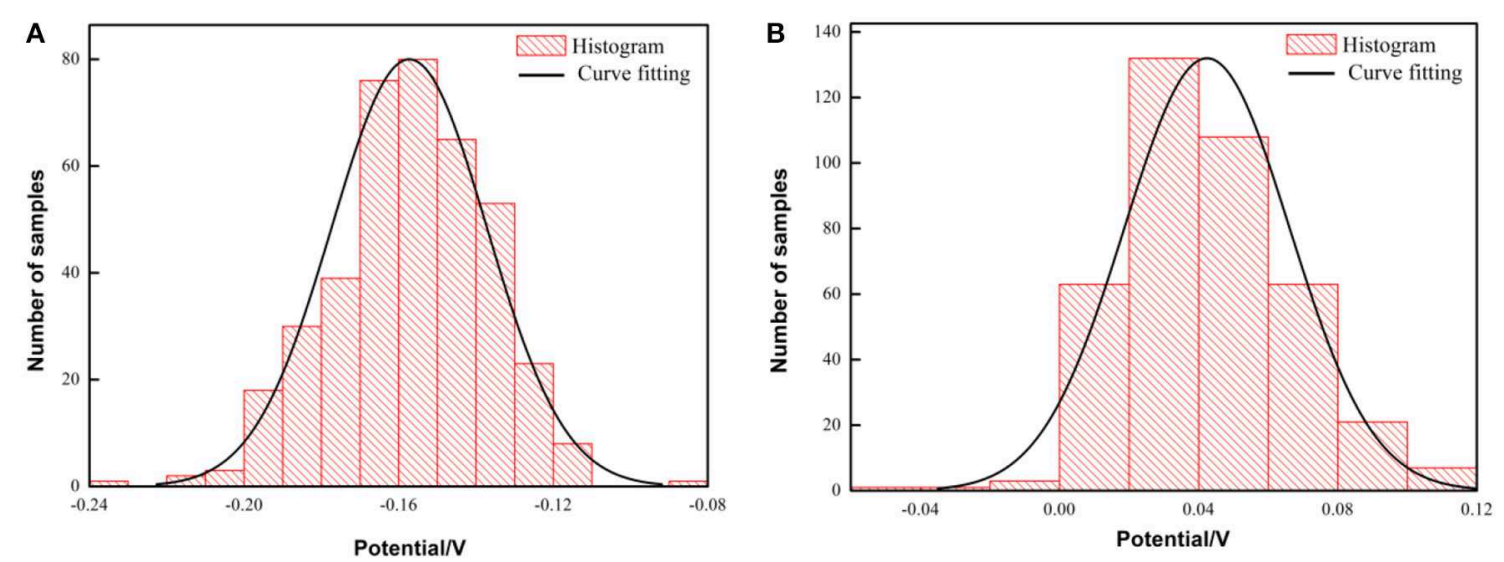

FIGURE 12 | Histogram and fitting curve of Kelvin potential distribution on the surface of PH13-8Mo stainless steel after exposure for 5 years (A) bare samples; (B) pre-passivated samples.

enhanced the repassivition to protect the propagation of the pitting corrosion. However, after 5 years of outdoor exposure, the difference in the ratio of $\mathrm{Cr}$ and $\mathrm{Fe}$ on the surface of the bare and the pre-passivated samples was much small, which also manifested that the pre-passivation treatment did have the protectiveness on the stainless steel, but the effect after long-term exposure revealed obvious boundedness of protection period.

\section{SKP}

To further study the protective effect of the pre-passivated film of the PH13-8Mo stainless steel, the surface Kelvin potential of the both samples after 5 year exposure was measured. The potential distribution was shown in Figure 11, and the surface potential $E_{k p}$ was fitted by a Gaussian equation, as shown in Figure 12. The chemical potential of electron $\mu_{\mathrm{e}}$ of the bare and the prepassivation sample was -0.1554 and $0.0377 \mathrm{~V}$, respectively.

It is found that the potential distribution uniformity between the bare sample and the pre-passivated sample surface is not much different. The value of $\sigma$ of the bare and the prepassivation sample was 0.0394 and 0.0383 , respectively. The potential difference was obvious between the different regions on the surface, which could be characterized as the localized corrosion. While, the potential distribution of the pre-passivation sample was more even, and the corresponding value of $\sigma$ was smaller. In addition, the Kelvin potential of the bare sample was much lower than that of the pre-passivated sample according to the Gaussian fitting results.

It was widely accepted that the dense passivation film was a semiconductor film, which strongly inhibited the escape of electrons ( $\mathrm{Wu}$ et al., 2017) and thus resulted in an increase in the surface Kelvin potential of the stainless steel. (SzklarskaSmialowska, 2002) believed that the breakdown of the passivation film by the electrons was one of the reasons for the initiation of pitting corrosion. Therefore, the higher Kelvin potential of the pre-passivated sample reflected that it was more difficult for the electrons to pass through the pre-passivation film, that was, the passivation film was much denser than that of the bare sample.
Herein, combined with Figures 9, 10, the surface of the prepassivated sample was covered with fewer corrosion products and the denser passivation film, and thus led to more positive surface Kelvin potential.

\section{CONCLUSIONS}

(1) The 5 year field exposure tests in industrial-marine atmospheric environment showed that, compared with bare steel, pre-passivation treatment inhibited the uniform and pitting corrosion of $\mathrm{PH} 13-8 \mathrm{Mo}$ stainless steel, that is, the area and depth of pitting are obviously reduced, and the average corrosion rates of the pre-passivated steels decreased by $14.7 \%$.

(2) Compared with the bare PH13-8Mo stainless steel, the higher ratio of $\mathrm{Cr} / \mathrm{Fe}$ and oxide/hydroxide, and the more positive and homogeneous Kelvin voltage potential for the surface of outdoor exposed pre-passivated steel inhibited the uniform and pitting corrosion.

(3) The pre-passivated PH13-8Mo stainless steel occurred pitting only after 1 year of exposure. The main reason is that the chromium-depleted passivation film near the Cr-rich precipitates is weak to prevent $\mathrm{Cl}^{-}$permeation and the pitting initiation and propagation, which led to a negative effect for the protection period of pre-passivation.

\section{DATA AVAILABILITY STATEMENT}

All datasets generated for this study are included in the article/supplementary material.

\section{AUTHOR CONTRIBUTIONS}

$\mathrm{YH}$ and YL conceived and designed the experiments. YL, QZ, and JZ performed the experiments. YL, XC, and LL analyzed the data. $\mathrm{YH}$ and $\mathrm{JZ}$ contributed reagents, materials, and analysis tools. YL wrote the paper. 


\section{FUNDING}

The authors wish to acknowledge the financial support of the National Key Research and Development Program

\section{REFERENCES}

Bonagani, S. K., Bathula, V., and Kain, V. (2018). Influence of tempering treatment on microstructure and pitting corrosion of $13 \mathrm{wt} . \% \mathrm{Cr}$ martensitic stainless steel. Corros. Sci. 131, 340-354. doi: 10.1016/j.corsci.2017.12.012

Button, H. E., and Simm, D. W. (1985). The influence of particulate matter on the corrosion behaviour of type 316 stainless steel. Anti Corros. Methods Mater. 32, 8-10. doi: 10.1108/eb020346

Carmezim, M. J., Simões, A. M., Montemor, M. F., and Belo, M. D. C. (2005). Capacitance behaviour of passive films on ferritic and austenitic stainless steel. Corros. Sci. 47, 581-591. doi: 10.1016/j.corsci.2004.07.002

Chen, X., Li, X. G., Du, C. W.,Z and Cheng, Y. F. (2009). Effect of cathodic protection on corrosion of pipeline steel under disbonded coating. Corros. Sci. 51, 2242-2245. doi: 10.1016/j.corsci.2009.05.027

Cheng, X. Q., Li, X. G., and Dong, C. F. (2009). Study on the passive film formed on 2205 stainless steel in acetic acid by AAS and XPS. Inter. J. Miner. Metall. Mater. 16, 170-176. doi: 10.1016/S1674-4799(09)60029-7

Chong, C., and Cheung, M. M. S. (2014). Non-uniform rust expansion for chloride-induced pitting corrosion in RC structures. Constr. Build. Mater. 51, 75-81. doi: 10.1016/j.conbuildmat.2013.10.042

Clayton, C. R., and Lu, Y. C. (1986). A bipolar model of the passivity of stainless steel: the role of Mo addition. J. Electrochem. Soc. 133, 2465-2473. doi: 10.1149/1.2108451

Cui, Z. Y., Chen, S. S., Wang, L. W., Man, C., Liu, Z. Y., and Wu, J. S., et al. (2017). Passivation behavior and surface chemistry of 2507 super duplex stainless steel in acidified artificial seawater containing thiosulfate. J. Electrochem. Soc. 164, C856-C868. doi: 10.1149/2.1901713jes

Dalmau, A., Richard, C., and Igual-Muñoz, A. (2018). Degradation mechanisms in martensitic stainless steels: wear, corrosion and tribocorrosion appraisal. Tribol. Int. 121, 167-179. doi: 10.1016/j.triboint.2018.01.036

Devaux, R., Vouagner, D., Becdelievre, A. M. D., and Duret-Thual, C. (1994). Electrochemical and surface studies of the ageing of passive layers grown on stainless steel in neutral chloride solution. Corros. Sci. 36, 171-186. doi: 10.1016/0010-938X(94)90118-X

Escrivà-Cerdán, C., Blasco-Tamarit, E., García-García, D. M., García-Antón, J., Akid, R., and Walton, J. (2013). Effect of temperature on passive film formation of UNS N08031 Crct of temperature on passive film formation of UNS ssive layerssive anions. Electrochim. Acta 111, 552-561. doi: 10.1016/j.electacta.2013.08.040

Friedrich, H., and Schumann, S. (2001). Research for a "new age of magnesium" in the automotive industry. J. Mater Process Technol. 117, 276-281. doi: 10.1016/S0924-0136(01)00780-4

Ghods, P., Isgor, O. B., Mcrae, G. A., and Gu, G. P. (2010). Electrochemical investigation of chloride-induced depassivation of black steel rebar under simulated service conditions. Corros. Sci. 52, 1649-1659. doi: 10.1016/j.corsci.2010.02.016

Goutier, F., Stéphane Valette, L. E., and Lefort, P. (2011). 304L stainless steel oxidation in carbon dioxide: an XPS study. J. Alloys Compd. 509, 3246-3251. doi: 10.1016/j.jallcom.2010.12.094

Guo, Q., Liu, J., Yu, M., and Li, S. (2015). Effect of passive film on mechanical properties of martensitic stainless steel $15-5 \mathrm{PH}$ in a neutral nacl solution. Appl. Surf. Sci. 327, 313-320. doi: 10.1016/j.apsusc.2014.11.154

Hu, Y. B., Dong, C. F., Sun, M., Xiao, K., Zhong, P., and Li, X. G. (2011). Effects of solution $\mathrm{pH}$ and $\mathrm{Cl}^{-}$on electrochemical behaviour of an aermet100 ultra-high strength steel in acidic environments. Corros. Sci. 53, 4159-4165. doi: 10.1016/j.corsci.2011.08.024

Imrie, W. M. (1970). Maraging steel in British aerospace industry. Metal Forming 37:15.

Jin, S., and Atrens, A. (1988). Esca-studies of the surface-film formed on stainlesssteels by exposure to $0.1 \mathrm{M} \mathrm{Nacl}$ solution at various controlled potentials. Appl. Phys. A 46, 51-65. doi: 10.1007/BF00615137 of China (No. 2016YFB0300604), the National Natural Science Foundation of China (Nos. 51971033, 51801011), and the National Materials Corrosion and Protection Data Center.

Klapper, H. S., Goellner, J., Burkert, A., and Heyn, A. (2013). Environmental factors affecting pitting corrosion of type 304 stainless steel investigated by electrochemical noise measurements under potentiostatic control. Corros. Sci. 75, 239-247. doi: 10.1016/j.corsci.2013.06.005

Kong, D. C., Ni, X. Q., Dong, C. F., Zhang, L., Man, C., Yao, J. Z., et al. (2018). Heat treatment effect on the microstructure and corrosion behavior of 316L stainless steel fabricated by selective laser melting for proton exchange membrane fuel cells. Electrochi. Acta 276, 293-303. doi: 10.1016/j.electacta.2018.04.188

Kraack, M., BöHni, H., and Muster, W. (1995). Influence of molybdenum on the corrosion properties of sputter-deposited stainless steel films. Trans Tech Public 192-194, 165-176. doi: 10.4028/www.scientific.net/MSF.192-194.165

Li, X. G., Zhang, D. W., Liu, Z. Y., Li, Z., Du, C. W., and Dong, C. F. (2015). Materials science: share corrosion data. Nature 527, 441-442. doi: $10.1038 / 527441$ a

Li, X. Y., Fan, C. H., Wu, Q. L., Dong, L. H., Yin, Y. S., Wang, C. J., et al. (2017). Effect of solution $\mathrm{PH} \mathrm{Cl}^{-}$, concentration and temperature on electrochemical behavior of ph13-8mo steel in acidic environments. J. Iron. Steel. Res. Int. 24, 1238-1247. doi: 10.1016/S1006-706X(18)30023-2

Lo, K. H., Shek, C. H., and Lai, J. K. L. (2009). Recent developments in stainless steels. Mater. Sci. Eng. R Rep. 65, 39-104. doi: 10.1016/j.mser.2009.03.001

Luo, H., Dong, C. F., Xiao, K., and Li, X. G. (2011). Characterization of passive film on 2205 duplex stainless steel in sodium thiosulphate solution. Appl. Surf. Sci. 258, 631-639. doi: 10.1016/j.apsusc.2011.06.077

Luo, H., Yu, Q., Dong, C. F., Sha, G., Liu, Z. Y., Liang, J. X., et al. (2018). Influence of the aging time on the microstructure and electrochemical behaviour of a 15-5PH ultra-high strength stainless steel. Corros. Sci. 139, 185-196. doi: $10.1016 /$ j.corsci.2018.04.032

Lv, J. L., Liang, T. X., Wang, C., and Guo, T. (2016). Influence of sensitization on passive films in AISI 2205 duplex stainless steel. J. Alloys. Compd. 658, 657-662. doi: 10.1016/j.jallcom.2015.10.246

Merl, D. K., Panjan, P., Cekada, M., and Maček, M. (2004). The corrosion behavior of Cr-(C,N) PVD hard coatings deposited on various substrates. Electrochim. Acta 49, 1527-1533. doi: 10.1016/S0013-4686(03)00953-8

Munn, P., and Andersson, B. (1990). Hydrogen embrittlement of PH13-8Mo steel in simulated real-life tests and slow strain rate tests. Corrosion 46, 286-295. doi: $10.5006 / 1.3585104$

Nazarov, A., and Thierry, D. (2007). Application of volta potential mapping to determine metal surface defects. Electrochim. Acta 52, 7689-7696. doi: 10.1016/j.electacta.2007.05.077

Phadnis, S. V., Satpati, A. K., Muthe, K. P., Vyas, J. C., and Sundaresan, R. I. (2003). Comparison of rolled and heat treated SS304 in chloride solution using electrochemical and XPS techniques. Corros. Sci. 45, 2467-2483. doi: 10.1016/S0010-938X(03)00099-4

Rodriguez, A. A., Tylczak, J. H., Gao, M. C., Jablonski, P. D., Detrois, M., Ziomek-Moroz, M., et al. (2018). Effect of molybdenum on the corrosion behavior of high-entropy alloys cocrfeni 2 and cocrfeni 2 mo 0.25 under sodium chloride aqueous conditions. Adv. Mater. Sci. Eng. 2018:3016304. doi: $10.1155 / 2018 / 3016304$

Ryan, M. P., Williams, D. E., Chater, R. J., Hutton, B. M., and McPhail, D. S. (2002). Why stainless steel corrodes. Nature 415, 770-774. doi: 10.1038/41 $5770 \mathrm{a}$

Seetharaman, V., Sundararaman, M., and Krishnan, R. (1981). Precipitation hardening in a PH 13-8 Mo stainless steel. Mate. Sci. Eng. 47, 1-11. doi: 10.1016/0025-5416(81)90034-3

Sugimoto, K., and Sawada, Y. (1977). The role of molybdenum additions to austenitic stainless steels in the inhibition of pitting in acid chloride solutions. Corros. Sci. 17, 425-445. doi: 10.1016/0010-938X(77) 90032-4

Szklarska-Smialowska, Z. (2002). Mechanism of pit nucleation by electrical breakdown of the passive film. Corros. Sci. 44, 1143-1149. doi: 10.1016/S0010-938X(01)00113-5 
Vignal, V., Ringeval, S., Thiébaut, S., Tabalaiev, K., Dessolin, C., and Heintz, O., et al. (2014). Influence of the microstructure on the corrosion behaviour of low-carbon martensitic stainless steel after tempering treatment. Corros. Sci. 85, 42-51. doi: 10.1016/j.corsci.2014.03.036

Wallinder, D., Wallinder, I. O., and Leygraf, C. (2003). Influence of surface treatment of type $304 \mathrm{l}$ stainless steel on atmospheric corrosion resistance in urban and marine environments. Corrosion 59, 220-227. doi: $10.5006 / 1.3277554$

Wang, J. R., Bai, Z. H., Xiao, K., Gao, X., Yi, P., Dong, C. F., et al. (2019). Influence of atmospheric particulates on initial corrosion behavior of printed circuit board in pollution environments. Appl. Surf. Sci. 467-468, 889-901. doi: 10.1016/j.apsusc.2018.10.244

Wang, K. R., Shi, R. H., Qu, J. E., Liu, S. B., Chen, G., and Guo, X. P. (2012). Reasearch on phytic acid passivation technology of stainless steel and corrosion resistance. J. Mater. Eng. 2, 77-81. doi: 10.3969/j.issn.1001-4381.2013.06.001

Wu, W., Cheng, X. Q., Hou, H. X., Liu, B., and Li, X. G. (2017). Insight into the product film formed on ni-advanced weathering steel in a tropical marine atmosphere. Appl. Surf. Sci. 436, 80-89. doi: 10.1016/j.apsusc.2017.12.018

Yan, L. D., Xiao, K., Yi, P., Dong, C. F., Wu, J. S., Bai, Z. H., et al. (2017). The corrosion behavior of PCB-ImAg in industry polluted marine atmosphere environment. Mater. Design. 115, 404-414. doi: 10.1016/j.matdes.2016.11.074 Yue, C. X., Zhang, L. W., Liao, S. L., Pei, J. B., Gao, H. J., Jia, Y. W., et al. (2009). Research on the dynamic recrystallization behavior of GCr15 steel. Mater. Sci. Eng. A 499, 177-181. doi: 10.1016/j.msea.2007.11.123

Zou, D. N., Liu, R., Li, J., Zhang, W., Wang, D., and Han, Y. (2014). Corrosion resistance and semiconducting properties of passive films formed on $00 \mathrm{Cr} 13 \mathrm{Ni} 5 \mathrm{Mo} 2$ supermartensitic stainless steel in $\mathrm{Cl}^{-}$environment. J. Iron Steel Res. Int. 21, 630-636. doi: 10.1016/S1006-706X(14)60098-4

Conflict of Interest: The authors declare that the research was conducted in the absence of any commercial or financial relationships that could be construed as a potential conflict of interest.

Copyright $\odot 2019 \mathrm{Liu}$, Zhao, Zhao, Huang, Cheng and Lu. This is an open-access article distributed under the terms of the Creative Commons Attribution License (CC $B Y)$. The use, distribution or reproduction in other forums is permitted, provided the original author(s) and the copyright owner(s) are credited and that the original publication in this journal is cited, in accordance with accepted academic practice. No use, distribution or reproduction is permitted which does not comply with these terms. 